\title{
Transcendence and Abjection in Vergílio Alberto Vieira's Cleptopsydra
}

ROBERT SIMON

Kennesaw State University

Abstract: In the present essay, I examine Portuguese poet Vergílio Alberto Vieira's 2018 collection, Cleptopsydra, an explicit parody on Camilo Pessanha's Clepsidra (1920). Within the collection, the poetic voice moves beyond the rigidity of Pessanha's form through a series of sublime, transcendent, but ultimately earthbound symbols. This tension between form, symbol, and transcendence likewise exists in the work of several of Vieira's contemporaries, and I suggest an openly transnational and translinguistic link between them. Finally, I discuss how contemporary Portugal has come to serve as both a challenge and a point of articulation for Vieira's poetics.

Keywords: Portuguese poetry, contemporary, Iberian Studies, différance, Camilo Pessanha

Portuguese poet Vergílio Alberto Vieira's 2018 collection, Cleptopsydra, is in a literal sense a loving parody on Camilo Pessanha's Clepsidra (1920). Throughout the collection, the poetic voice consistently moves beyond the rigidity of Pessanha's sonnet form through a series of sublime, transcendent symbols. These contrast with the poems' harsh and earthly themes, a tension that forms the center of my analysis. Also, given that this tension (among others) likewise exists in the work of several of Vieira's Iberian contemporaries, such as Clara Janés, Blanca Andreu, Joaquim Pessoa, and Jesús Jiménez Reinaldo, I suggest an openly transnational and translinguistic link between them. Finally, I discuss how 
contemporary Portugal has come to serve as both a challenge and a point of articulation for Vieira's poetics.

\section{Pessanha and the Real}

Clepsidra was the only collection of poetry that Pessanha published during his lifetime; nonetheless, he did mange to compose and publish several poems and short stories before his death in 1926. These compositions evince a strong current of fin-de-siècle decadence, but they also came to serve as the Saudosist, orientalist basis for Portuguese modernism (Garay 194). Clepsidra itself has served as a reference point for how a poet clearly working within an orientalist framework (and from the vantage point of a secondary European power) may attempt honestly to narrate and yet still exoticize the Asian other. As Gérard M.M. Siary argues:

Dans la partie européenne de Macao, distincte de la ville chinoise, on vend son savoir, on passe du temps avec les compatriotes, on tâche de trouver quelque intérêt au lieu où l'on se trouve. A partir du moment où il débarque à Macao le 10 avril 1894 où il sera professeur, puis secrétaire de lycée et enfin juge, CP ne va cesser de manifester, malgré maux professionnels et déboires de santé, une pensée désirante à l'endroit de la société locale : opium, femmes, objets d'art, etc. Cette curiosité, à l'origine de l'orientalisme, n'est pas toujours le fait de savants, mais de négociants, de militaires, de diplomates. Le lettré Pessanha, ainsi que d'autres amateurs, cultive l'intérêt pour la culture et la civilisation locales, qu'il intègre à sa propre substance. (Siary 177)

[In the European quarter of Macao, separate from the Chinese city, one sells one's knowledge, one spends time with one's compatriots, one attempts to find any interest in the place where one finds oneself. From the moment Camilo Pessanha arrives in Macao on 10 April 1894 (where he will be a teacher and then a school principal and finally a judge), he will never cease to manifest, despite underemployment and bad health, an attraction 
to the place: opium, women, art objects, etc. This curiosity, at the very center of Orientalism, is not always a trait of scholars but also of businesspeople, soldiers, and diplomats. The well-read Pessanha, as with other connoisseurs, cultivates an interest in local culture and civilization, which he integrates into his own substance.]

Siary clearly delineates Pessanha's unusual perspective vis-à-vis his exoticized poetic object. As is made plain here, the over-application of topics surrounding the decadence of Europe becomes revealing of both the self-loathing that characterizes literary discourse of the period and the mal-applied metaphorical scaffold in the context of a relatively defenseless literary and colonial subject. "Curiosity" and the rich symbolism of a failing cultural model thus manifest as the suppression of the colonial subject's own discourse, leaving only the word of the colonizer and the alterity thrust upon the colonized in its wake. The parallel Vieira creates through his parodic re-writing of Pessanha's collection highlights the similarities that exist between our own vapid, posthuman reality and the superficiality of colonial discourse during Pessanha's time.

An examination of the criticism on orientalist thought in Pessanha's collection brings several contradictions to the surface. Duarte Nuno Drumond Braga, for example, critiques Esther de Lemos's earlier analysis in the following way: “O fenómeno orientalista é percepcionado pela autora do ponto de vista moral: uma condenação do outro que deve ser, por sua vez, condenada pelo crítico. Perde-se assim o essencial, a desconstrução daquele discurso, que, nestas condições, não consegue ser feita de forma plena” (143). The notion that a poetics of alterity can both create an image of the exotic and become the object of its own exoticism bears the weight of Pessanha's thematic development in Clepsidra. Given the more recent focus on language and a movement away from topos, Braga's perspective makes sense: "Na crítica mais recente, os poemas de Camilo Pessanha estão sendo mais abordados conforme experiências com a linguagem, o que ajudou a diminuir a interferência de 'mitos' sobre o autor que muito contribuíam para distorcer a sua recepção pelos leitores” (Picosque, par. 4). This mythos of Pessanha's personage and his poetic subject's grasp of what one might consider an abject experience of the "exoticized real" moves the reader toward a metalinguistic and self-critical stance regarding their own grasp of 
Simon

contemporary reality. This questioning of the real as abjection bears fruit in Vieira's poetic experience.

\section{Vieira and Postmodern Spleen}

Vieira began his career as a poet after returning to Portugal from the colonial war in Angola. Shocked by the inhumanity of the conflict and ready to reflect on the experience, his first works, such as Ritual negro (1973) and Terra interior (1978), did just that. Since then, he has published poetry, essay, short stories, children's stories, and critical essays on literature. He currently serves as editor for the literary and art journal Quaderna: literatura y arte.

Vieira's desire to move toward an epistemology of the sublime as an alternative to the more acerbic discourse of many of his post-colonial contemporaries, took his poetic work in a different direction beginning in the 1980s. Moving into the twenty-first century, Vieira's work has expressed ever more the simultaneity of sociopolitical space, mystical discourse, and diachronic perspectives with regard to influences of past and present authors. Cleptopsydra is no exception.

Vieira's collection stems from an appreciation for Pessanha's own expressive epistemology. As Vieira sees it, it serves to: "reflectir a imagem deste nosso mundo igualmente spleenático, a tal ponto temos acesso a tudo-e à insatisfação que daí decorre; nada de descrições, ou tão-só uma súmula rápida dando a impressão dos objectos” (Cleptopsydra 9). Put another way, Vieira delves into the alterity of the deeper self in the context of the superficial realities the poetic subject faces in the contemporary world. The notion of a "súmula rápida,” both as imitation and re-inscription, takes center stage.

It should also be noted that Vieira had already published a short commentary concerning Pessanha's work before composing Cleptopsydra. In it, he refers to the metaphor of silence and its link to corporeal death and/or transformation:

Pela sua parte, o poeta de Clepsidra apenas sabe que vive, que viver será, quando menos se pensa, ou talvez não, o encontro com a morte. [...] É então que à opacidade necessária da linguagem o poeta contrapõe a transparência verbal do silêncio, esse ínvio idioma que, dando curso à segmentação de impressões e imagens 
de um fazer poético aprendido em Verlaine, fala agora de um eu, de um outro eu que, através da combinação rítmica e sonora, se sobrepõe ao sentido poético para comunicar, em última instância, o que à essência unitária da poesia pertence. (“7 de Setembro de 1867," 2)

In this description of Modernist rhythmic and sonorous techniques, there is a point of recognition on Vieira's part for what, in his own poems, will be reborn as the transliterary and ontological tensions present in the first several poems of Cleptopsydra. In this citation, Vieira recounts the binary oppositions of silence and "transparência verbal" as a moment in which Pessanha initiates a process of unifying the multiplicity of the poetic word with the essence the poetic voice seeks out through the knowledge that "vive, que viver será, quando menos se pensa [...] o encontro com a morte.” As a close reading of Vieira's work will show, his poetic subject turns the critical stance above into a parodic, symbolic environment-a world in the most literal sense-in which both a detachment from the false reality of the physical world and a subsequent search for the real through a mystical process take precedence.

One may also notice in Cleptopsydra the political criticism common in works of other contemporary Portuguese poets. As Ernesto Rodrigues points out in his prologue: "Vieira acolhe o inevitável trânsito dentro da lucidez que o cinismo dos tempos modernos requer [...] opera transformações inesperadas, que obrigam a apanhado breve do que entendemos por intertexto, em sentido lato” (15). The collection signals the recognition of an ontological crisis and a subsequent call for change; however, Vieira also proves capable of fitting this discourse into his exploration of more openly mystical thought (and in this case, of course, the failure of that thought) within the context of late modernity. The collection begins with a moment of awakening filled with painful, somnambular nostalgia:

Já sonhos tive, e cruéis n'alma indolente

Senti que envelhecia, de resto prematuro

Indo à deriva, do passado do futuro

Sem tempo de saber se foi presente. 
Saudades de viver só as que procuro

Agora que as não tenho, já somente,

Depois de as ter tido, quem as sente

Ignora a dor chorada, verbo 'scuro.

Cansado de sofrer, há-de ser dia

De esquecer a noite, essa agonia

D’alma que, a medo, a razão demora.

É que vencido, o espaço da jornada

Não queira pois a hora desejada

Entregar à morte um coração que chora. (21)

Readers of Pessanha will immediately notice that this poem relates closely to "Caminho I," the opening poem of Clepsidra:

Tenho sonhos cruéis; n’alma doente

Sinto um vago receio prematuro.

Vou a medo na aresta do futuro

Embebido em saudades do presente...

Saudades desta dor que em vão procuro

Do peito afugentar bem rudemente,

Devendo, ao desmaiar sobre o poente,

Cobrir-me o coração dum véu escuro!...

Porque a dor, esta falta d'harmonia,

Toda a luz desgrenhada que alumia

As almas doidamente, o céu d'agora,

Sem ela o coração é quase nada:

Um sol onde expirasse a madrugada.

Porque é só madrugada quando chora. (4) 
The repetition of symbols is notable; nevertheless, differences in wording point to a transformation of the interior life of the poetic subject in Vieira's adaptation. For example, the fifth verse of Pessanha's poem reads: "Saudades desta dor que em vão procure,” which Vieira changes to: “Saudades de viver só as que procuro." The change from the noun dor to the nominalized verb viver turns the search for exoticized pain in Pessanha's poem into a longing for a life one has not experienced. In this way, saudades, a sign of nostalgic longing, becomes displaced from a position of alterity to one of direct (dis)connection. The inverse metonymy of saudade (with its distancing in the physical world and simultaneous rapprochement within the exoticized subconscious) becomes an integral binary opposition both within Vieira's poem and through its diachronic link to Pessanha's “Caminho I.”

The complex binary opposition forged by Vieira's reworking of Pessanha resonates with a poetics that has been a feature of Portuguese verse since the 1980s. At its core, this poetics works to disclose the falsity of the world and clear a path for what lies beyond. ${ }^{1}$ One finds a clear example of this in Joaquim Pessoa's Os olhos de Isa (1983), which contains the following verses: "Festejo o teu corpo com uma chuva de lâmpadas / e rosas clandestinas” (131). Here hidden roses (of the earth) and a rain of light from the sky stand in opposition; however, their moment of contact gives way to the possibility of a truth ("o teu corpo") that lies beyond image and language.

\section{Pessanha and Post-Saudosist Poetics}

Celestial and earthly symbols are also typical of late nineteenth- and early twentieth-century Portuguese poetics, particularly in the Saudosist movement most notably represented by Teixeira de Pascoaes during the late nineteenth century. Ana da Conceição Figueiredo Martins makes this point explicitly:

O pensamento de Teixeira de Pascoaes faz bastante sentido, nestes tempos de crise nacional e mundial, não só económica, mas essencialmente de valores, em que necessitamos desesperadamente de uma alternativa capaz, de uma força motriz

\footnotetext{
${ }^{1}$ For more on this, see Simon, “Entre as forças.”
} 
impulsionadora de soluções. Pascoaes nas desilusões, nas contrariedades e dificuldades políticas e sociais do seu tempo profetizou, preconizou, veiculou na Arte de Ser Português, o perfil e o caminho para melhorarmos, encontrando no Saudosismo a alavanca adequada para elevar o país à condição de um estado, humana e universalmente, superior. (41)

Teixeira de Pascoaes's critical yet proudly nationalistic position serves as a precursor to Pessanha's exoticizing yet tender post-Saudosist verse. What emerges from the comparison, in fact, is the creation of a third space between these normally competing tendencies. Turning back to Vieira, and specifically to his capacity for original poetic expression within an explicit project of imitatio, one is at once struck by Pessanha's adherence to Teixeira de Pascoaes's Saudosist symbolism and Vieira's own post-deconstructionist polysemy.

The second poem of Vieira's collection, “Estátua,” continues building on the possibilities of opposition even as it leads to an unfortunate but perhaps predictable impasse:

Afastei-me para evitar esse degredo,

Tentada ausência, p'ra poder esquecê-lo

Antes de ser sentença sem apelo

Sumida em fundo pélago, qual segredo

Tornado má-fortuna, inquieto medo

De estátua grega cujo pesadelo

A deixou perdida, já depois de sê-lo

Como cativo que se fez rochedo.

Jazente sombra, apesar do corpo alado,

Que o frio mármore reteve sempre erecto, Há-de doer-lhe o torso reclinado

Outrora concebido pelo escopro liberto

De quem o pensou nunca imaginado

Por serenas mãos de um Fídias incerto. (24) 
The soft parody of Pessanha's "Estátua" (6) is evident. It is worth noting, however, that the formal structure of Pessanha's poem, with verses organized in a semi-Shakespearean sonnet scheme (4-4-3-2), differs from Vieira's choice of a Petrarchan sonnet form (4-4-3-3). The reader confronts other slight changes in the lexical choices Vieira makes: rather than speaking about a physical object, exoticizing it, and then building a universe of alterity around it as Pessanha does, Vieira moves away from the ekphrastic and speaks of the statue as part of a metonymy of disquiet and alienation. In this sense, while Pessanha views the sculpted object as a symbol of nature's dichotomous contradictions, Vieira presents contradiction as an inherent part of an already deconstructed ontology. Thus, the image of the statue for Vieira refers most directly to a failed attempt to reach the sublime.

\section{The Mystics of Failure}

Like Vieira, Navarrese poet Jesús Jiménez Reinaldo speaks at length of the failure of illumination in his first collection, La mística del fracaso (2002). In the poem "Ronda tierna" (13), for example, Jiménez Reinaldo reveals a tense scene of anti-illumination:

Nunca jamás

rememora su voz hasta seis veces

bajo tañidos lúgubres. En ésta la noche

idéntica y dilatada, cuando la ronda felina

de Wendy, ya para veinte años.

A medianoche

la consigna exige que el tiempo se detenga, que silenciosas sombras se delineen en cotejos antiguos, copien recuerdos dudosos. Entre galerías, tristemente vacías.

Wendy

exhibe desvelada, sin el temor lumínico 
del espejo, zarpazos restañados en las mejillas, desacostumbrada: ¿qué arrugas inéditas, qué maldición eterna soporta tu corazón ingenuo, íntimo y niño en la penumbra?

[Never again

will her voice call out six times

in mournful peals. On this night, identical and dilated, the feline and round

form of Wendy, now just about twenty.

At midnight

the chant demands that time stop, that silent shadows line up in ancient comparison, that they imitate doubtful memories. Among galleries, sadly empty.

Wendy

now shows, without the mirror's

luminous fear, healed wounds on her cheeks, unaccustomed: what new wrinkles, what eternal curse does your innocent heart bear, intimate and childlike in the darkness?]

The poem references the canonical children's novel Peter Pan through the name "Wendy" and its use of the phrase "Nunca jamás” ('Never again'), which most likely refers to Neverland. However, the space open in the poem is not one of hope but one of negation. In the terrible moment detailed above, a tortured Wendy finds herself alone in an empty, dark space. She has lost her youth to a violence thinly covered by her seemingly innocent dance (hence the "zarpazos" ('wounds,' as those caused by sharp claws), reminiscent of the vital suffering seen in such works as César Vallejo’s seminal poem “Los heraldos negros” 'The black heralds'), and as such is now unable to reach any sort of transcendence. As with Vieira's reworking of Pessanha, this failure manifests itself within the "penumbra” or space between binary oppositions. In Wendy's case, it is a 
negation of forward movement within an ontologically entrapping ronda; Vieira's Cleptosydra puts in place a similar ronda through the work's consistent intertextual parody.

As in Pessanha's Clepsidra, there is also a degree of political commentary in Vieira's collection. The poem "Fonógrafo" exemplifies this:

Assim vai discursando um político defunto.

Na praça pública ri do que mais mente

O comício que, a rir, tanto o consente

Que nem dá pela anacrónica falta de assunto.

Registado o logro, insiste gabarola, Delírios, risos aceitam a falcatrua.

Com tal paleio, alguém grita: rua!

E logo a dabandada, que já ninguém controla.

Por toda a parte se precipitam os filhos

Da nação, se libertam empecilhos

Que sempre atravancaram por tudo e por nada.

É hora pois de não ir mais em tretas;

De fingir que a coisa menos arriscada

Será tomar alguém por rei das petas. (33)

An evident satirical critique of politicians and their egotism takes center stage in Vieira's poem; nonetheless, its fidelity to a decidedly Pessanha-esque framework of rhythm and rhyme is in keeping with the formal aspects of other poems in the anthology.

The final poem of Vieira's collection may serve as a summary of themes examined in the present essay. One finds in it the articulation of a transcendent alterity based on poetic structures laid down by Pessanha in his late Saudosism and on his exoticization of the physical world. The result of this articulation, as Vieira makes clear, is a failure to produce any sort of meaningful illumination. As part of this, Vieira adds a deconstructive element to this already complex 
symbolic matrix, forging a path of fractured epistemology and incomplete experience:

Miragens que passais pela retina,

Areia imensa, a que deserto olhar

Regressais, breve engano, sombra benina

De outra sombra, p’ra não mais ficar?

Miragens que passais, onde termina

Vosso curso ardente, tornado, mar

Infindo mar, não de água cristalina,

Mas de ausência, e muito desejar?

Sem voz, contrariando a lei da morte,

Ainda o vento - de que confins virá

Em estátuas de sal dar-se à sorte?

Há-de fazer-se ouvir, talvez morrer

De olhos abertos - que diferença fará

Se é lei da morte voltar a nascer. (43)

The imagery in these verses finds its center in a physical world where false images ("breve engano, sombra benina / de outra sombra") takes precedence over truth. Even in this superficial world, however, the cycle of birth, death, and rebirth remains powerful and constant. In the final stanza, for example, Vieira states explicitly that any attempt at giving voice may well be fruitless, even pointless, given the unshakeable cycle of death and rebirth. Here birth and death move in a never-ending cycle, such as in the work of Clara Janés. ${ }^{2}$ The abject becomes reality, and oppositions open up a questioning of physical reality that engenders the doubt one needs to seek out a new space for knowledge. This third

\footnotetext{
2 Such cycles may be found in several of her works, including her 2005 collection Fractales, in which the binary oppositions of night and day, light and dark, birth and death, etc., fold into the ultimate process of rebirth (Simon, "El misticismo geométrico,” 166-68).
} 
space between discourses is likely a poetic reference to what Jacques Derrida referred to as différance (44).

In the final poem of Cleptosydra, nature's presence and absence do not resolve into any recognizable (or secure) binary opposition The poetic subject is thus resigned to a wholly unsatisfying reality, one in which superficiality has unmoored itself from depth, its “natural” contrary. Portuguese poet Pedro Mexia (1972- ), further develops this idea:

Olho para mim, como se fosse

a pessoa da mesa em frente

(que não olha para lado

nenhum) e reparo como estamos

todos, neste café, a fazer

o que é próprio da nossa idade

ou a lamentar não o

fazermos ou a lamentar

a idade

e que visto de fora (mas teria

de ser mesmo de fora deste

poema) isto é um jogo animado

de bonecos psicológicos e biodegradáveis,

cada um com o penteado

e os sapatos que lhe são próprios,

exuberantes ou ensimesmados pensando

que havemos de ser todos parecidos,

ou já fomos. (14)

The poetic subject rides a perspectival wave of angles outward, attempting in vain to reach a deeper understanding of the spatial relation between self and other. This process only leads to a much less profound possible reading of the space, however, one that never moves beyond the reflections already in view. In this context, the reader is then reminded of the very real possibility that the past could have led to a comprehension of some deeper meaning (“já fomos”); 
however, the present cannot. The poem ends as an endless circle of possibility and impossibility, of untapped potential in a contemporary context. ${ }^{3}$

Returning to Vieira's Cleptosydra, what on the surface looks to present itself as a parody of Pessanha's Clepsidra also reveals a (necessarily) frustrated search for more profound truths at the start of the new century. Here the peripheral (through parody) presents a third space of possible articulation and epistemological/ontological grounding. It bears mentioning that a similar engagement with the peripheral also appears in the work of Galician poet Blanca Andreu. Most criticism highlight the intense presence of surrealism in her work (Alaya-Dip 224), as well as a gynocentrism that works to counteract a misogynist norm (Wilcox 298). Her use of a combination of surrealist and mystical symbols, rooted in the Portuguese literary tradition and a notably critical aesthetic, allows her reader to engage in a critique of contemporary Galician society while also offering potential resolutions. ${ }^{4}$ The case of Andreu, along with Vieira and others, points to a general tendency within contemporary Iberian letters toward transnational discourse, especially within the Lusophone sphere.

In contemporary Portugal, there is a strong sense that the liberal state has descended into a critical juncture of globalization, nationalist politics, and commercializing, neo-liberal policies. The results of this recombination have been economic instability and a widening gap between individual identity and macro-level ideals of social commodification. These tendencies (including, but not limited to, the political negotiations leading to the geringonça of the past five years) have led to a widening gap between rich and poor. ${ }^{5}$ As recently as 2011, in fact, Portugal "was one of the most unequal countries in the European Union, with the continent's second highest Gini coefficient for disposable household income" (Campos-Matos 2). In other words, contemporary Portugal operates more as an oligarchy than as a thriving democracy, and this has negatively

\footnotetext{
${ }^{3}$ Although, again, Mexia's poem does not explicitly adhere to any sort of mystical process, it importantly highlights binary oppositions as a false start to a world unready for deeper comprehension of itself. This aspect of his work links it directly with the mystical discourse of his contemporaries, whether or not it was his purpose to do so. This becomes, then, another contextual clue as to the current state of Iberian poetics in the twenty-first century and the transposition of mystical and non-mystical tendencies in contemporary poetics.

${ }^{4}$ For more on these aspects of Andreu's work, see Mudrovic; Simon, From Post-Mortem.

${ }^{5}$ For more on the Portuguese Left's coalition government, initially dismissed by conservatives as a geringonça, see Freire.
} 
impacted public faith in institutions that have largely served as guardians of a fixed socioeconomic scheme. As Vasco Ramos argues, the inability of Portuguese society to respond to a public desire for upward mobility, growth, and a deeper sense of self-actualization has become decisive:

O conjunto de resultados obtidos, em particular a diferença observada no acesso à trajetória de maior qualificação e acesso ao emprego técnico, confirma que a uma igualdade teórica no acesso não corresponde, maquinalmente, uma 'igualdade de oportunidades.’ As profissões mais qualificadas, que sempre gozaram de prestígio social, passaram a fazer parte das aspirações e anseios de mobilidade dos progenitores e dos seus investimentos, materiais e outros, na educação dos filhos, sobretudo a partir do momento em que se tornaram relativamente mais acessíveis por via da expansão do ensino superior. Mas a verdade é que as substanciais diferenças no ponto de partida, em termos de classe social, tanto em termos de recursos materiais como educacionais, continuam a ser decisivas para explicar as trajetórias de classe. (646)

Social class and education walk together, and the result is that Portuguese society neither modernizes nor progresses in any meaningful sense.

The official government response to class and racial inequality has been to profess "blindness," a practice that belies any claim to progressive action (Madeiros 256). This disconnect, exacerbated by the post-2008 financial crisis, has allowed a space for the superficial to open. It is for this reason that one finds such a mordant critique of conformity and intellectual posturing in Pedro Mexia's poetry. It is also in this vein that one must read Vieira's parody of Pessanha's poetic exoticism and sociopolitical vacuity, an epistemological approach that serves as the basis for Cleptopsydra. As Vieira's reworking of Pessanha also shows, the symbolic structures that give form to the poetic subject's internal struggle also shape the acerbic lens through which one is to see the external. While the Spanish Generación Nocilla has largely eschewed any concern with transcendence, more experimental poets such as Ana Rossetti and Andreu have nonetheless spent the last few decades developing this path (Simon, From Post- 
Mortem 35-39). In this context, essentialism does not contest the vacuous hierarchies of contemporary society; rather, it serves to highlight the opposition between itself and its context.

A good deal of Iberian poetry over the past two decades has struggled to work through dichotomies such as internal/external, deep/superficial, and truth/contingency. Through a thoughtful parody of the "essência unitária" that shapes Pessanha's Clepsidra, Vieira moves from an anti-hierarchical space where individual pain and social criticism intersect to one in which the abject subject turns to a form of transcendent symbolism more than casually linked to Iberian mysticism. This shift has served to highlight the commodified reality in which readers move and interact even as it has highlighted the unfortunate consequences of this reality.

\section{Works Cited}

Ayala-Dip, J. Eernesto, and Julio Llamazares. "Blanca Andreu y los surrealismos.” Historia y crítica de la literatura española, edited by Francisco Rico, vol. 9, no. 1, 1992, pp. 223-28.

Braga, Duarte Nuno Drumond. Ao oriente do oriente: transformações do orientalismo em poesia portuguesa do início do século XX (Camilo Pessanha, Alberto Osório de Castro e Álvaro de Campos). 2014, U de Lisboa, PhD Dissertation.

Campos-Matos, Inês, et al. "Connecting the Dots on Health Inequalities: A Systematic Review on the Social Determinants of Health in Portugal." International Journal for Equity in Health, vol. 15, no. 26, 2016, doi.org/10.1186/s12939-016-0314-z.

Derrida, Jacques. Positions. Translated by Alan Blas, U of Chicago P, 1981.

Freire, André. Para lá da 'geringonça': o governo de esquerdas em Portugal e na Europa. Contraponto, 2017.

Garay, René P. “Camilo Pessanha.” Dictionary of Literary Biography, vol. 287 (Portuguese Writers), edited by Mônica Rector and Fred M. Clark, Gale, 2004, pp. 194-98.

Jiménez Reinaldo, Jesús. La mística del fracaso. Devenir, 2002.

Lemos, Esther de. A Clépsidra de Camilo Pessanha: notas e reflexões. Tavares Martins, 1956. 
Madeiros, Paulo. "Exit Ghost: Reading Lusotropicalism as a Fetish (with Adorno).” Portuguese Studies Review, vol. 26, no. 1, 2018, pp. 247-71.

Martins, Ana da Conceição Figueiredo. Teixeira de Pascoaes e Leonardo Coimbra: Confluências. 2016, U de Universidade de Trás-os-Montes e Alto Douro, PhD Dissertation.

Mexia, Pedro. Eliot e outras observações. Gótica, 2003.

Mudrovic, W. Michael. Mirror, Mirror on the Page: Identity and Subjectivity in Spanish Women's Poetry (1975-2000). Lehigh UP, 2008.

Pessanha, Camilo. Clepsidra e outros poemas. Edited by João de Castro Osório, Ática, 1992.

Pessoa, Joaquim. Obra poética. Litexa, 2001.

Picosque, Tatiana Aparecida. "Branco e vermelho: ponto de contato entre a poética de Camilo Pessanha e a de Herberto Helder.” Fronteira Z, No. 5, 2010. revistas.pucsp.br/fronteiraz/article/view/12292/8900.

Ramos, Vasco. "Que trajetórias de classe? uma análise da mobilidade social em duas gerações de portugueses.” Análise Social, vol. 212, no. 3, 2014, pp. 62649.

Rodrigues, Ernesto. "Um amor em visita.” Cleptopsydra by Vergílio Alberto Vieira, Crescente Branco, 2018, pp. 7-17.

Siary, Gérard M. M. "Portrait de l'artiste en sinologue : Camilo Pessanha (18671926) et la Chine.” Studia Litterarum, vol. 1, no. 3-4, 2016, pp. 174-83.

Simon, Robert. "Entre as forças da fantasia e a duplicação do aforismo: o verso mítico/místico em A adivinhação pela água (1991) e O ilusório ponto do geómetra (2014) de Vergílio Alberto Vieira.” Romance Notes, vol. 57, no. 1, 2017, pp. 97-105.

-. From Post-Mortem to Post-Mystic: Blanca Andreu, Galicia, and the New Iberian Mysticism. Lexington, 2019.

Vieira, Vergílio Alberto. “7 de Setembro de 1867.” O Escritor, 2009, pp. 27072.

-. Cleptopsydra. Crescente Branco, 2018.

—. Ritual negro. Ecos do Norte, 1973.

—. Terra interior. Centelha, 1978.

Wilcox, John. Women Poets of Spain, 1860-1990: Toward a Gynocentric Vision. U of Illinois P, 1997. 